\title{
Effect of phytoderivatives on the growth of homologous beneficial vaginal lactobacilli (BVL) strains and their compatibility for the design of phytobiotics for the vaginal tract health
}

\section{Antonella Marchesi}

Consejo Nacional de Investigaciones Cientificas y Tecnicas

\section{Jessica Salva}

Consejo Nacional de Investigaciones Cientificas y Tecnicas

Cecilia Aristimuño Ficoseco

Consejo Nacional de Investigaciones Cientificas y Tecnicas

\section{Birgitt Wiese}

Medizinische Hochschule Hannover

Maria Elena Fatima Nader-Macias ( $\nabla$ fnader@cerela.org.ar)

CERELA-CONICET https://orcid.org/0000-0001-7526-1860

\section{Research}

Keywords: Beneficial Vaginal Lactobacilli (BVL), Phytoderivatives, Design of vaginal formula, Probiotic properties, Phytobiotics.

Posted Date: February 3rd, 2020

DOl: https://doi.org/10.21203/rs.2.22448/v1

License: (c) (1) This work is licensed under a Creative Commons Attribution 4.0 International License. Read Full License 


\section{Abstract}

Background: Lactobacilli are the predominant bacteria in the vaginal tract, and while they are present, can prevent infectious situations, being used as probiotics for the health of the tract. Phytoderivatives are used historically to prevent or maintain the health of the tract, and is possible to combine both bioactives for novel vaginal formulas.

The aim of this work was to study the effect of phytoderivatives (individual or combined extracts) on the growth of homologous vaginal lactic acid bacteria and their compatibility, to go further in the design of a combined pharmabiotic formula for the prevention or treatment of urogenital tract infections.

Methods: the effect of phytocompounds approved by Pharcopoeias was evaluated on the growth of beneficial lactic acid bacteria previously isolated from the vaginal tract. Statistical methods, as CART, were applied to determine the stimulatory or inhibitory effect of the vegetal sources on bacterial growth by applying different methodology. Compatibility between phyto and lactobacilli was determined, and the phenolic compounds contents quantified, to define the optimal conditions for the formula design.

Results: The BVL strains showing highest growth values with most of the phytoderivatives under study were L. gasseri CRL 1361, L. ga. CRL 1509 and L. ga. CRL 1263, and L. jensenii CRL 1333 and L. jen. CRL 1317 , indicating the behavior is strain-dependent, and vegetable-compound-affected. The most adequate phytoderivatives were: Carica, Centella, Plantago, Uva ursi*, Zarzaparrila*, Cola de caballo, Echinaceae, Ortiga and Palo Azul.

Conclusions: The BVL strains showing optimal resistance to the phytocompounds and compatibility with them were L. gasseri CRL 1320, 1307, 1509, L. salivarius CRL 1296 and L. rhamnosus CRL 1332 combined with Uva ursi*, Zarzaparrilla* and Echinaceae that will be used for the design of optimal phytobiotic formulas.

\section{Introduction}

The new concept of microbiome on the human and animal mucosa demonstrated during the last decade and the high variety of related functions described, supports the application of probiotic formulations designed with host and tract homologous microorganisms. Lactobacilli are a diverse group of more than 200 different species that occupy diverse nutrient-rich niches associated with humans, animals, plants and food [1]. They are used widely in biotechnology and food preservation, and are being explored as therapeutics [2]. Lactobacilli and other Generally Regarded as Safe (GRAS) and Qualified Presumption of Safety (QPS) genera are widely used as probiotics, which can be administered to help the host in the restoration of the indigenous microbiota, stimulate the immune system, or either protect against the income of pathogenic microorganisms. On the other side, there is an ever-growing interest on natural ingredients, including vegetal sources, derivatives and formula, both by consumers and producers in the food and pharma industries. In fact, people are looking for those products in the market which are free from artificial and synthetic additives and can promote their health, many of them with a very long 
application supported by concepts or custom-derived uses. In the ethnopharmacological area, the knowledge related to the traditional uses of medicinal plants is totally in the custody of elder community members and local herbalists [3]. A long list of them is included in the Pharmacopeia resources, indicating they can be used safely for different situations [4, 5]. Historically, they were used with different proposals, effects reviewed by different authors [6]. Also, the limitation of the therapeutic options for emerging multidrug resistance microorganisms, and the urgent need of new (or old-uses) natural and safe combinations is emerging [7]. Then, the concept of phytobiotics has been conceived, to combine safe phytoderivatives and probiotic bacteria for the design of new formulations, resulting in the combination/synergy of the two beneficial effects. These bioactive ingredients should be formulated in such a way that they are compatible, protects them against harsh process and environmental conditions and could be delivered safely to the target organs and cells.

On the probiotic area, our research group has a long history of experiments performed "in vitro" or in animal models, complemented by studies on the design of different type of vaginal probiotic formula [8, $9,10]$. Then, the aim of this work was to study the effect of phytoextracts (macerated or powders) on the growth of homologous vaginal probiotic lactobacilli (by applying different methods) and their compatibility to select those than can be combined for the design of phytobiotic formulas. The growth kinetics and compatibility assays were designed and evaluated through the application of specific statistical models, to select those with an optimal behavior. Also, the phenolic content was evaluated, and the best combination defined to go further in the design of different type of formulas for the reproductive tract health.

\section{Materials And Methods}

\section{Bacterial strains and growth conditions}

The bacterial strains used in this study were beneficial vaginal lactic acid bacteria (BVLAB) (Lactobacillus reuteri, L. gasseri, L. rhamnosus, L. salivarius L. delbrueckii, L. johnsonii, L. paracasei) isolated from women vagina (Tucuman, Argentina). They are included in Table 1, together with their beneficial properties previously determined $[8,9,10,11,12]$. Microorganisms were stored in milk-yeast extract $(13 \%$ non-fat milk, $0.5 \%$ yeast extract and $1 \%$ glucose) at $-20^{\circ} \mathrm{C}$ [8]. Before the experiment they were subcultured three times, and later grown in MRS broth (BIOKAR, Argentina) for $13 \mathrm{~h}$ at $37^{\circ} \mathrm{C}$. BVLB were inoculated at $2 \%$ for the experimental assays, and incubated for 12 and 24 hours at $37^{\circ} \mathrm{C}$. The third subculture was monitored by optical density measurements at $560 \mathrm{~nm}$ (O.D.560nm) (Spectronic 20, Baush and Lomb, Roscherter, NY), until reaching an O.D. of 0.9-1.0, corresponding to $1 \times 10 e^{6}-1 \times 10 e^{8} \mathrm{CFU} / \mathrm{ml}$.

\section{Genetic Identification of lactic acid bacteria.}

The method applied to identify the BVL selected by their beneficial characteristics by the application of molecular-related techniques is described in previous works [13]. The strains, as identified by this method, are included in Table 1. 


\section{Vegetal material sources}

The natural solid compounds assayed were obtained from SAPORITI (Buenos Aires, Argentina), and selected from the phytoderivate compounds lists approved by the Pharmacopoeia (Argentinean Farmacopea [4]; European Farmacopea[5]) for human applications: Allium sativa (Ajo), Vaccinium myrtillus (Arandano), Atropa belladonna (Belladona), Peumus boldo (Boldo), Hydrocotyle asiática (Centella), Echinacea angustifolia (Echinaceae), Arctostaphylos Uva-ursi (Uva ursi), Matricaria recutita (Manzanilla), Smilax aspera (Zarzaparrilla) and Lapacho (Lapacho) [14, 15, 16, 17]. Suspensions of 30, 15 and $7.5 \mathrm{mg}$ dissolved in $1 \mathrm{ml}$ of $40 \%$ alcohol were used (obtaining cloudy solutions or suspensions). Liquid natural compounds were obtained from Fitot Laboratory (Tucuman- Argentina) elaborated by maceration: Aesculus hippocastanum, Capsella bursa-pastoris, Hydrocotile asiatica, Hamamelis virginiana, Caléndula officinalis, Matricaria recutita, Bacharis articulata, Mentha pulegium, Equisetum arvenseu, Mentha piperita, Betula pendula, Minthostachys mollis, Taraxacum officinale, Chelidonium majus, Peumus boldus, Cynara scolymus, Rosmarinus officinalis, Fabiana imbricata, Amaranthus muricatus, Dryopteris filix mas, Cuassia amara, Dysphania ambrosioides, Mentha pulegium, Ruta graveolens, Cyclolepis genistoides, Alternanthera pungens, Geoffroea decorticans, Achyrocline satureioides, Aloysia polystachya, Acrtostaphylos uva-ursi, Smilax aspera, Urtica dioica). The phytocompounds were used in $40 \%$ ethanol as solvent. The extracts, listed in Table 2 , were stored at $4^{\circ} \mathrm{C}$ until use. All of the phytoderivatives under assay were selected by their ethno-pharmacological properties described in Pharmacopoeia and used for human applications. They can be applied either as oral route, external uses (skin surface) or by the two ways (Table 3 and Table 4).

\section{Growth Kinetics of BVLAB with phytocompounds by Microplate technique}

Polystirene microplates (Extragen microplate -ELISA plate 96 well) wells were filled with the $150 \mu \mathrm{l}$ of MRS broth (Biokar, Argentina) inoculated with BVL at $2 \%$. Later, $50 \mu \mathrm{l}$ of each one of the liquid phytocompounds was added to the wells, gentle mixed and incubated at $37^{\circ} \mathrm{C}$ during $24 \mathrm{~h}$. The bacterial growth was determined by optical density (O.D.560nm) (Spectronic 20, Baush and Lomb, Roscherter, NY) at $3,6,9,12$ and $24 \mathrm{~h}$ at $37^{\circ} \mathrm{C}$. The growth kinetics were plotted to evaluate the behavior of each one of the strains with the different phytocompounds. Solvents, individual phytocompounds, and strains grown in MRS were included as control. All the experiments were performed by triplicate. The growth kinetics to indicate the effect of the phytocompounds on each strain was plotted, and also used to calculate the percentage of the maximal O.D. in MRS broth, represented in the color table as: Stimulating effect: high ("H-S": > 70\%), medium ("R-S": 70\%-35\%) or low ("L-S": <35\%). Inhibitory effect. high ("H-I": > 70\%), medium ("R-I": 70\%-35\%) or low (“L-I”: <35\%). No significant effect: “N-E” (No effect).

\section{Compatibility between microorganisms and phytocompounds by the plate agar diffusion technique}

MRS agar plates (Biokar, Argentina) (1\% agar) were inoculated with $100 \mu \mathrm{l}$ of different concentrations of BVL ( $1 \times 10 \mathrm{e}^{6}$ and $\left.1 \times 10 \mathrm{e}^{7} \mathrm{CFU} / \mathrm{ml}\right)$. Holes of $4 \mathrm{~mm}$ were aseptically prepared in the agar plates, and later inoculated with $25 \mu \mathrm{l}$ of serial dilutions in $40 \%$ ethanol (from $30 \mathrm{mg} / \mathrm{ml}$ ) of each one of the 
phytocompounds under study, settled for diffusion, and later incubated in microaerophyllic conditions at $37^{\circ} \mathrm{C}$. The inhibitory halos were measured after $48 \mathrm{~h}$ (in millimeters). Controls included the solvent used for each one of the phytocompounds. The assays were performed for triplicate [18].

\section{Quantification of polyphenolic content in natural compounds}

The photometric assay was applied to quantify the phenolic concentration in the phytocompounds under study [19] and the absorbance was determined at $750 \mathrm{~nm}$ using a UV-VIS spectrophotometer (Spectronic 20, Baush and Lomb, Roscherter, NY). The calibration curve was obtained with Gallic Acid (GA) (Sigma Aldrich, Argentina) as standard (concentration range 2.5-1000 $\mu \mathrm{g}$ ) with ethanol as control (Sigma-Aldrich; Merck KGaA, Darmstadt, Germany). The regression equation was: $y=0.0395 x+0.1633$, and the coefficient of correlation $\mathrm{R} 2=0.9907$. The results were expressed in $\mathrm{mg}$ GAE $\cdot \mathrm{g}-1$ extract. The experiments were performed by triplicate.

\section{Statistical evaluation.}

The bacterial growth parameters were estimated applying the 4-parameter modified Gompertz-model:

$$
O D=N 0+A^{\star} \exp \left\{-\exp \left[\left(\mu^{\star} e / A\right) \star(\lambda-t)+1\right]\right\}
$$

where OD is the optical density at time $t$ (time of growth in hours), NO the OD at $t=0, A$ the difference between the final and the initial ODs, $\mu$ the maximum specific growth rate $\left(h^{-1}\right), \lambda$ the lag phase time in hours and e the base of the neperian logarithm.

For the estimation of the parameters constrained nonlinear regression was performed. This method uses a sequential quadratic programming algorithm. For the parameter standard errors and confidence intervals the method of Bootstrapping was applied, using repeated samples from the original data set. For each growth curve 100 bootstrap samples were taken.

To identify subgroups of combinations of strains with phytocompounds with optimal growth a Classification and Regression Tree (CART) analysis was performed. The CART analysis is capable of detecting complex interactions of variables that might be missed by standard statistical approaches. The estimated growth parameter A was included as independent variable and the parameters strain and phytocompound were included as predictors in the analysis. Only experiments with an estimated parameter A (O.D.) of at least 0.8 and an estimated lag phase shorter than $8 \mathrm{~h}$ were selected for the CART analysis.

For the analyses and graphical presentations the statistical programs SPSS 25, S-Plus 8.1 and STATISTICA 12 were used. The CART analysis was performed with Salford Predictive Modeler 8.2. [20].

\section{Results}

Growth of BVL in presence of different extracts 
The growth of many strains was affected by the phytocompound under assay, because they were either stimulated of inhibited. The complete list of phytoderivatives assayed is shown in Table 2. Some examples of the effect of phytocompounds on the BVL growth are indicated in Figure 1 and 2 that means the effect of each one of the vegetal compounds on the different BVL is strain-specific, and no related with the metabolic groups in which they were originally classified. The claimed effects of all the phytoderivatives under assay are shown in Table 2 and 3 , being no related to the inhibitory effect produced on the BVL growth.

The growth of the strains at $37^{\circ} \mathrm{C}$ was evaluated through O.D.560nm every 3 hours, being different in each one of the associations of the different strains and phytocompounds. Those bacteria that had a higher O.D. ${ }_{560 \mathrm{~nm}}$ than 0.8 and less than 8 hours lag phase were chosen to plot in the graphs. Some examples are shown in Figure 1: A- B: represent obligate homofermentative bacteria $(\mathrm{OHe})$; C- D: facultative heterofermentative ( $\mathrm{FHe})$, and $\mathrm{E}-\mathrm{F}$ : to obligate homofermentative lactobacilli $(\mathrm{OHo})$. The growth in standard media (MRS) of each strain of lactobacillus is represented by a dotted line. Figure $A$ and $B$ show the behavior of L. reuterii CRL 1324 and L. reuterii CRL1327. The strains are stimulated by Carica (Car) and Betula (Bet*), and both of them inhibited by Chelidonium (Che*) and Echinacea (Ech). But, L. reuterii CRL 1327 is highly stimulated by Carica (Car) and Betula (Bet*), and more inhibited by Centella (Cen).

Figures $C$ and $D$ show the growth of $L$. rhamnosus CRL 1511 and L. rhamnosus CRL 1332 indicating that the strain CRL 1332 was not affected by Carica (Car) and Betula (Bet*), while favored the L. rhamnosus CRL 1511 growth.

Lactobacillus jensenii CRL 1333 and Lactobacillus gasseri CRL 1264 growth were plotted in Fig E and F; Chelidonium (Che*), Lippia (Lip*) and Echinaceae (ECh) affected the growth of the two strains. However L. jensenii CRL 1333 growth was slightly inhibited by Centella (Cen).

In most of the BVL evaluated, Betula (Bet*) and Carica (Car) extracts did not show an inhibitory effect on their growth.

Related to the optimal concentration of vegetal extracts to be used, Figure 2 shows that different concentration of Allium sativa (Fig 2B, 2C, 2D), Hamamelis (Fig 2E, 2F, 2G) and Uva ursi (Fig 2H, 2l, 2J) exert an inhibitory effect on the BVLAB growth related with the increased concentration of the phytoextracts added, being higher when adding $3 \mathrm{mg} / \mathrm{ml}$ than $0.75 \mathrm{mg} / \mathrm{ml}$. Further studies are required to determine if the strains would be able to grow after an induction or adaptation phase, previously to their use for the technological application.

\section{Liquid Phytocompounds and BVL: "Classification and regression tree analysis"}

With the experimental data obtained from the combination of all the phytocompounds (Table 2,3 ) and lactic acid bacteria strains (Table 1), the growth parameters of each one of the strains associated with each phytoderivative was calculated. The cut point established were O.D.: 0. 8, lag phase shorter than $8 \mathrm{~h}$, and incubation time 24 hours, with these conditions 184 trials were selected for the analysis. The 
statistical evaluation performed through the CART (Classification and regression tree analysis) software, showed the following results:

The selected trials show a mean estimated O.D. of 1.007 growth (Fig. 3). The algorithm then divides the "root node" containing all selected trials into two nodes using the variable "strain", including 128 assays with an average growth of 0.938 O.D. (BVL in the box "Terminal Node 1"), while on the right 56 trials are included with an average growth of 1.163 O.D. ("Node 2"). Node 2 is then divided using the predictor "phytocompound". The resulting "Terminal node 2" includes 29 trials with an average growth of 1.026 O.D., while "Node 3 " includes 27 trials showing an average growth of 1.309 O.D.

"Node 3" is then split into two terminal nodes using the predictor "strain": "Terminal Node 3" includes 18 assays with an average growth of 1.182 O.D. and "Terminal node 4" contains 9 trials with an average growth of 1.564 O.D.

Hence the CART analysis identifies four subgroups of trials (terminal nodes) with an average growth ranging from 0.938 O.D. to 1.564 O.D.

\section{BVL and phytocompounds compatibility.}

The behavior of 24 BVL classified into different metabolic groups were assayed with 25 different natural alcoholic extracts. The degree of interaction between BVL and the vegetal extracts is summarized in Table 5, showing the compatible or non-compatible combinations: stimulatory (green) or inhibitory effect (red) of the phytocompounds on the growth of each strain. The BVL growing with the phytoderivatives is indicated with different colors: green boxes: "High Stimulation", (higher of $70 \%$ growth than in control MRS broth); light-green color "Medium Stimulation" (between 70\% and 35\% growth higher than control) and "Low Stimulation" (35\% higher growth than the control). At the same time, the red boxes indicated "High Inhibition" (70\% decrease of the maximal growth compared with control), while orange boxes represent "Medium Inhibition" (those strains inhibited between 70\% and 35\%); pink boxes "Low Inhibition" (BVL inhibited lower than 35\%); The yellow boxes, "No Effect", did not modify their growth with phytoderivatives when compared with control MRS.

The results summarized in Table 5 indicate that behavior or growth of each one of the BVL strain under evaluation was different depending on the phytocompound added to the assay. Some of the phytoderivatives showed a similar behavior when added to BVL, as for example: "Medium Stimulation": Carica papaya (Car), Yerba meona (Yme), Echinacea (Ech), Zarzaparrilla (Zar), Palo azul (Paz) and Ortiga (Ort). "Medium Inhibition" was produced by Lippia (Lip*), Perilla (Per), Zarzaparrilla (Zar*) and Hamamelis (Ham*), while "No effect" was detected with Zarzaparrilla (Zar), Uva ursi (Uva) and Palo azul (Paz).

The BVL strains showing highest growth, indicating their compatibility with most of the phytoderivatives under study were L. gasseri CRL 1361, L. gasseri CRL 1509 and L. gasseri CRL 1263; L. jensenii CRL 1333, 
L. jensenii CRL 1317. The strains strongly inhibited by most of the phytocompounds were $L$. fermentum CRL 1287 and L. salivarius CRL 1296.

Uva ursi (Uva) and Zarzaparrilla (Zar) did not affect ("N-E") the growth for L. reuteri CRL 1327, L. reuteri CRL 1324 and L. rhamnosus CRL 1511.

However, Yerba meona (Yme) showed a High Stimulating ("H-S") effect against strains classified into different metabolic groups such as: L. gasseri CRL 1263, L. gasseri CRL 1320 and L. gasseri CRL 1261. But, some strains were affected by Yerba meona (Yme) with a Medium Stimulating ("R-S") effect. $L$. reuteri CRL 1324, L. salivarius CRL 1328, and L. reuteri CRL 1327, L. rhamnosus CRL 1332 and L. mucosae CRL 1508 had a Low Stimulation (L-S) compared with the control.

L. gasseri CRL 1261 showed a better results, because the growth was favored by most of the phytocompounds evaluated (supplementary material).

The pure extract of Yerba meona (Yme), Palo azul (Paz) and Echinaceae(Ech), as well as the mixtures corresponding to Carica (Car), Calendula (Cal) and Betula (Bet*) did not significantly affect the growth of lactic acid bacteria.

\section{Phenolic content in the phytocompounds}

The phenolic compounds were quantified trying to define it they are related with their beneficial effect or compatibility with BVL. All the phytoextracts showed to contain phenolic compounds in different quantities, showed in Fig 4, where eleven extracts with content higher than $500 \mu \mathrm{g}$ eq Galic acid/ml are indicated. Hamamelis showed the higher content of phenolics. Manzanilla and Zarzaparrilla did not show significant differences among them, as well as Echinaceae, Chelidonia and Zarzaparrilla*. Echinaceae and Yerba meona did not show significant differences between them. Betula and Perilla did not have a significant difference, however, Plantago presented a significant difference with Betula, but not with Perilla.

\section{Discussion}

The use of phytoderivatives is generally transmitted as a consequence of their ancient applications, most of them lately rediscovered, or under stronger evaluation. Scientists have published some experimental data related with isolated vegetal derivatives, for example on specific infections of urogenital pathogens, as Candida vaginal infections [21], some viruses [22], and parasites as Trichomonas [23] or bacteria [24]. In addition, they are widely recommended and included in the design of vegetal-derived formulas for postmenopausal women or for reproductive disorders [25].

It is widely known that Uva ursi and Ortiga have shown antibacterial properties against different microorganisms [26] showing results that were expected. But Hamamelis and Aesculus that are natural derivatives used by their vascular properties, mainly to improve the venous circulation, have shown some 
results that were not expected. Many of them were used for the inhibition of pathogens related with the tract, as shown in Table 2 and 3.

On the other side, the use of Lactic acid bacteria as probiotics at different mucosal sites is widely recommended $[27,28]$. Then, is possible to combine those phytoderivatives currently or historically applied to the urogenital tract with beneficial lactic acid bacteria with probiotic properties in a way to design different formula directed to exert or produce a synergistic effect on the host. In this way, is of main importance to determine if the phytoderivatives affect the BVL growth and if they are compatible to be used in a unique beneficial formula. The results of this work shows the interactions of a long list of phytoderivatives approved in the Pharmacopeias to be used either for oral or local administration with probiotics BVL characterized in our laboratory. There is no many data on the compatibility of phytoderivatives and vaginal lactobacilli strains published. The paper of Murina [29] reports the administration of a vaginal gel containing Thymus vulgaris and Eugenia caryophillus in conjunction with two Lactobacillus strains specifically formulated in slow-release capsules in treating bacterial vaginosis, or recurrent vulvovaginal candidiasis disease, recommended their use in the acute treatment. But there is no previous studies reporting the compatibility between the two bioactives constituents of the commercial formula. Then, is of main importance, and as the first step for the formula design, to evaluate the effect of the phytoderivatives, either as liquids or extracts on the BVL growth. The results obtained in this work indicate that the effect is phytoderivative and strain dependent, because there is no general rules. Each strain and each extract must be asssayed in a way to define their optimal or adequate combinations. The classification of lactobacilli into metabolic groups supported by their sugar-catabolic ways, either as homofermentative or heterofermentative, does not predict or indicate any type of compatibility, resistance or behavior when combined with the wide variety of vegetal derivatives under assay. The evaluation of their combinations was performed in this work through the growth kinetics, and by MIC assays, allowing to define which of them could be combined adequately.

The very high number of experimental protocols applied to determine the compatibility of the two bioactives under study did not allowed to define and decide promptly the optimal or most adequate combination. Then, the use of statistical models, and the CART analysis is a widely applied tool to define the most adequate combinations, when a huge number of analytical or experimental data are available [30]. The application of statistical methods, and CART analysis, have contribute to go further in the decision and selection of the most adequate BVL strains and phytoderivatives in a way to combine them in a phytobiotic formula. The results indicate that the most adequate phytoderivatives to be combined with BVL are Carica, Centella, Plantago, Uva ursi*, Zarzaparrilla*, Cola de Caballo, Echinaceae, Ortiga and Palo azul.

The concentration of the phenolic compounds on the extract is not directly correlated with the effect on the BVL growth or in the compatibility between them. Further studies must be performed to determine if some specific type of components is responsible of the stimulatory or inhibitory effect.

\section{Conclusion}


The BVL strains showing compatibility with the phytoextracts were L. gasseri CRL 1320, 1307, 1509, L. salivarius CRL 1296 and L. rhamnosus CRL 1332 with Uva ursi*, Zarzaparrilla* and Echinaceae, which were selected supported by their ethnopharmacological effects (antibacterial, anti-inflammatory and healing) for the further design of phytobiotic formula

\section{Declarations}

Ethics statements: not applicable.

Data statements: the data included in the manuscripts are original, and had not been published previously. They were not submitted to other scientific editorial. All the authors agree on the data and results included in the manuscript.

Availability of data and materials: please contact author for data request.

Funding statements: this work was supported by grants received from CONICET PIP 545 and ANPCYT (PICT 1187 and 4324) referred to design of the study, collection of data and writing the manuscript. Also, was carried out under the Cooperation between Mincyt (Argentina) and BMBF (Germany), project AB02 that supports the analysis and interpretation of data.

Competing interest: The authors declare that they have no competing interests.

\section{Authors' contributions}

1. Experimental procedures. References acquisition. Draft of results.

JAS. Experimental procedures. Draft of results

CAF. Genetic identification of the strains

1. Validation. Statistical evaluation.

MEFN: Conceptualization; Formal analysis; Funding acquisition; Investigation; Methodology; Supervision; Writing - original draft; review \& editing.

Acknowledgements: not applicable

\section{Bibliography}

[1] List of prokaryotic names with standing in nomenclature for the French version and English version, 1997. http://www.bacterio.net/index.html.

[2] Sun Z, Harris HMB, McCann A, Guo C, Argimón S, Zhang W, Yang X, Jeffer IB, Cooney JC, Kagawa TF, Liu W, Song Y, Salvetti E, Wrobel A, Rasinkangas P, Parkhill J, Rea MC, O'Sullivan O, Ritari J, Douillard FP, Ross RP, Yang R, Briner AE, Felis GE, de Vos WM, Barrangou R, Klaenhammer TR, Caufield PW, Cui Y, 
Zhang H, O'Toole PW. 2015. Expanding the biotechnology potential of lactobacilli through comparative genomics of 213 strains and associated genera. Nat Commun. 6:8322. doi: 10.1038/ncomms9322.

[3] Aziz MA, Khan AH, Adnan M, Izatullah I. 2017.Traditional uses of medicinal plants reported by the indigenous communities and local herbal practitioners of Bajaur Agency, Federally Administrated Tribal Areas, Pakistan, J Ethnopharmacol. 198:268-281. doi: 10.1016/j.jep.2017.01.024.

[4] Instituto Nacional de Medicamentos - INAME. Administración Nacional de Medicamentos, Alimentos y Tecnología Médica- ANMAT-. FARMACOPEA ARGENTINA, 1993, 2003, 2006, 2009, 2013, 2015, 2018. Cuarta- Séptima- Octava Edición- Anexos. Buenos Aires.

[5] European Directorate for the Quality of Medicines \& Health Care (EDQM), 2018. FARMACOPEA EUROPEA.

[6] Sakkas H, Economou H, Gousia P, Bozidis P, Sakkas VA, Petsios S, Mpekoulis G, Ilia A, Papadopoulou C. 2018. Antibacterial Efficacy of Commercially Available Essential Oils Tested Against Drug-Resistant Gram-Positive Pathogens. Applied sciences. https://doi.org/10.3390/app8112201.

[7] Kok ET, Jong MC, Gravendeel B, Van Leeuwen WB, Baars EW. 2015. Resistance to Antibiotics and Antifungal Medicinal Products: Can Complementary and Alternative Medicine Help Solve the Problem in Common Infection Diseases? The Introduction of a Dutch Research Consortium. Evid Based Complement Alternat Med. doi: 10.1155/2015/521584.

[8] Ocaña VS, Pesce De Ruiz Holgado AA, Nader-Macías ME. 1999. Characterization of a Bacteriocin-Like Substance Produced by a Vaginal Lactobacillus salivarius Strain. Appl Environ Microbiol. 65(12): 56315635 .

[9] De Gregorio PR, Juárez Tomás MS, Nader-Macías ME. 2016. Immunomodulation of Lactobacillus reuteri CRL1324 on Group B Streptococcus Vaginal Colonization in a Murine. Experimental Model. Am J Reprod Immunol. 75(1):23-35. doi: 10.1111/aji.12445.

[10] Leccese Terraf MC, Mendoza LM, Juarez Tomas MS, Silva C, Nader MEF. 2014. Phenotypic surface properties (aggregation, adhesion and biofilm formation) and presence of related genes in beneficial vaginal lactobacilli. J Appl Microbiol. 117(6):1761-72. doi: 10.1111/jam.12642.

[11] Nader-Macías ME, Juárez Tomás MS. 2015. Profiles and technological requirements of urogenital probiotics. Adv Drug Deliv Rev. 92:84-104. doi:10.1016/j.addr.2015.03.01.

[12] Juárez Tomás MS, Wiese B, Nader-Macías ME. 2005. Effects of culture conditions on the growth and auto-aggregation ability of vaginal Lactobacillus johnsonii CRL 1294. J Appl Microbiol. 99(6):1383-91.

[13] Fosch SE, Ficoseco CA, Marchesi A, Cocucci S, Nader-Macias MEF, Perazzi BE. 2018. Contraception: Influence on Vaginal Microbiota and Identification of Vaginal Lactobacilli Using MALDI-TOF MS and 16S rDNA Sequencing. Open Microbiol J. 12:218-229. doi: 10.2174/1874285801812010218. 
[14] Alonso J, Desmarchelier C. 2015. Plantas Medicinales. Bases Científicas para su Aplicación en Atención Primaria de la Salud. 1a ed. - Ciudad Autónoma de Buenos Aires. Corpus Libros Médicos y Científicos. CDD 615.321.

[15] Campagna MN, Di Sapio O, Gattuso M. 2013. Parámetros micrográficos para la identificación de hojas, corteza y leño de Picrasma crenata (Vell.). Engl. (Simaroubaceae). Dominguezia - Vol. 29(1).

[16] Martinez GJ. 2005. Recolección y Comercialización de Plantas Medicinales en el departamento Santa María, Provincia de Córdoba, Argentina. Acta Farm. Bonaerense 24 (4): 575-84.

[17] Servicio de Salud Arica, Subsecretaria de Redes Asistenciales, Ministerio de Salud, Gobierno de Chile. 2013. Arturo Prat 305, Arica. Servicio de Salud Arica.

[18] De Gregorio PR, Silva JA, Marchesi A, Nader-Macías MEF. 2019. Anti-Candida activity of beneficial vaginal lactobacilli in in vitro assays and in a murine experimental model. FEMS Yeast Res. 19(2). doi: 10.1093/femsyr/foz008.

[19] Danciu C, Muntean D, Alexa E, Farcas C, Oprean C, Zupko I, Bor A, Minda D, Proks M, Buda V, Hancianu M, Cioanca O, Soica C, Popescu S, Dehelean CA. 2018. Phytochemical Characterization and Evaluation of the Antimicrobial, Antiproliferative and Pro-Apoptotic Potential of Ephedra alata Decne. Hydroalcoholic Extract against the MCF-7 Breast Cancer Cell Line. Molecules. 24 (1). pii: E13. doi: 10.3390/molecules24010013.

[20] Breiman L, Friedman JH, Olshen RA, Stone CJ. 1984. Classification and Regression Trees. Chapman \& Hall (Wadsworth, Inc.): New York.

[21] Zida A, Bamba S, Yacouba A, Ouedraogo-Traore R, Guiguemdé RT. 2017. Anti- Candida albicans natural products, sources of new antifungal drugs: A Review. J Mycol Med. 27(1):1-19. doi: 10.1016/j.mycmed.2016.10.002.

[22] Kaushik NK, Guha R, Thomas BM. 2017. Antiviral potential and mode of action of Indigofera heterantha against HSV-2 by targeting the early stages of infection. Antivir Ther. 22(5):381-391. doi: 10.3851/IMP3118.

[23] Calzada F, Yépez-Mulia L, Tapia-Contreras A. 2007. Effect of Mexican medicinal plant used to treat trichomoniasis on Trichomonas vaginalis trophozoites. J Ethnopharmacol. 113(2):248-51. doi: 10.1016/j.jep.2007.06.001.

[24] Marchiori D, Zanello PP. 2017. Efficacy of N-acetylcysteine, D-mannose and Morinda citrifolia to Treat Recurrent Cystitis in Breast Cancer Survivals. In Vivo. 31(5): 931-936.

[25] Depypere HT, Comhaire FH. 2014. Herbal preparations for the menopause: Beyond isoflavones and black cohosh. Review. Maturitas. 77(2):191-4. doi: 10.1016/j.maturitas.2013.11.001. 
[26] Bone K, Mills S. 2013. Principles and Practice of Phytotherapy. 2nd Edition. Modern Herbal Medicine. Hardcover ISBN: 9780443069925. doi: http://dx.doi.org/10.1016/B978-0-443-06992-5.00010-4.

[27] International Scientific Association for Probiotics and Prebiotics (ISAPP). 2016. International Scientific Association for Probiotics and Prebiotics. https://isappscience.org.

[28] McFarland LV, Evans CT, Goldstein EJC. 2018. Strain-Specificity and Disease-Specificity of Probiotic Efficacy: A Systematic Review and Meta-Analysis. Front Med (Lausanne). 5:124. https://doi.org/10.3389/fmed.2018.00124.

[29] Murina F, Vicariotto F, Di Francesco S. 2018. Thymol, Eugenol and lactobacilli in a medical device for the treatment of bacterial vaginosis and vulvovaginal candidiasis. New Microbiol. 41(3):220-224. ISN $1121-7138$.

[30] Ito A, Hayashi M, Hamasaki T, Ebisu S. 2011. Risk assessment of dental caries by using Classification and Regression Trees. J Dent. 39(6):457-63. doi: 10.1016/j.jdent.2011.04.002.

\section{Tables}

Table 1. Lactobacillus strains used in this work and their main probiotic characteristic. 


\begin{tabular}{|c|c|c|c|}
\hline Metabolic group & Lactobacillus strains & Beneficial characteristics & References \\
\hline \multirow[t]{11}{*}{$\begin{array}{c}\text { Obligate } \\
\text { homofermentative }\end{array}$} & L. gasseri CRL1252 & $\mathrm{H}_{2} \mathrm{O}_{2}$ production, high hydrophobicity, pathogens inhibition & $\begin{array}{l}\text { Ocaña et al. 1999; } \\
\text { Juárez Tomas et } \\
\text { al. 2011; } \\
\text { De Gregorio et al. } \\
2019\end{array}$ \\
\hline & L. gasseri CRL1255 & $\mathrm{H}_{2} \mathrm{O}_{2}$ and lactic acid production, pathogens inhibition & $\begin{array}{c}\text { Ocaña et al. } \\
\text { 1999; } \\
\text { Juárez Tomas et } \\
\text { al. 2011; } \\
\text { De Gregorio et al. } \\
\quad 2019\end{array}$ \\
\hline & L. gasseri CRL1256 & $\mathrm{H}_{2} \mathrm{O}_{2}$ and lactic acid production, pathogens inhibition & $\begin{array}{c}\text { Ocaña et al. } \\
\text { 1999; } \\
\text { Juárez Tomas et } \\
\text { al. 2011; } \\
\text { De Gregorio et al. } \\
2019\end{array}$ \\
\hline & L. gasseri CRL1261 & $\mathrm{H}_{2} \mathrm{O}_{2}$ production, high hydrophobicity & $\begin{array}{c}\text { Ocaña et al. } \\
\text { 1999; } \\
\text { De Gregorio et al. } \\
2019 \\
\end{array}$ \\
\hline & L. gasseri CRL1263 & $\begin{array}{l}\mathrm{H}_{2} \mathrm{O}_{2} \text { and lactic acid production, high hydrophobicity, pathogens } \\
\text { inhibition, colonization of BALB/c mice vaginal tract, adhesion to } \\
\text { fibrinogen and mucin }\end{array}$ & $\begin{array}{l}\text { Ocaña et al. 1999; } \\
\text { De Gregorio et al. } \\
2019\end{array}$ \\
\hline & L. gasseri CRL1264 & $\mathrm{H}_{2} \mathrm{O}_{2}$ and lactic acid production & $\begin{array}{l}\text { Ocaña et al. 1999; } \\
\text { De Gregorio et al. } \\
2019\end{array}$ \\
\hline & L. gasseri CRL1265 & $\begin{array}{c}\mathrm{H}_{2} \mathrm{O}_{2} \text { and lactic acid production, high hydrophobicity, pathogens } \\
\text { inhibition }\end{array}$ & $\begin{array}{c}\text { Ocaña et al. } \\
\text { 1999; } \\
\text { Juárez Tomas et } \\
\text { al. 2011; } \\
\text { De Gregorio et al. } \\
\quad 2019\end{array}$ \\
\hline & L. gasseri CRL1268 & $\mathrm{H}_{2} \mathrm{O}_{2}$ production, pathogens inhibition & $\begin{array}{c}\text { Ocaña et al. } \\
\text { 1999; } \\
\text { Juárez Tomas et } \\
\text { al. 2011; } \\
\text { De Gregorio et al. } \\
2019\end{array}$ \\
\hline & L. gasseri CRL1270 & $\mathrm{H}_{2} \mathrm{O}_{2}$ production, pathogens inhibition, selfaggregation & $\begin{array}{c}\text { Ocaña et al. } \\
\text { 1999; } \\
\text { Juárez Tomas et } \\
\text { al. 2005, 2011; De } \\
\text { Gregorio et al. } \\
2019\end{array}$ \\
\hline & L. gasseri CRL1290 & $\mathrm{H}_{2} \mathrm{O}_{2}$ production & $\begin{array}{l}\text { Ocaña et al. 1999; } \\
\text { De Gregorio et al. } \\
2019\end{array}$ \\
\hline & L. gasseri CRL1307 & $\begin{array}{c}\mathrm{H}_{2} \mathrm{O}_{2} \text { and lactic acid production, high hydrophobicity, pathogens } \\
\text { inhibition }\end{array}$ & $\begin{array}{l}\text { Ocaña et al. } \\
\text { 1999; } \\
\text { Juárez Tomas et } \\
\text { al. 2011; }\end{array}$ \\
\hline
\end{tabular}




\begin{tabular}{|c|c|c|c|}
\hline & & & $\begin{array}{l}\text { De Gregorio et al. } \\
\qquad 2019\end{array}$ \\
\hline & L. gasseri CRL1311 & $\mathrm{H}_{2} \mathrm{O}_{2}$ production, high hydrophobicity & $\begin{array}{l}\text { Ocaña et al. 1999; } \\
\text { De Gregorio et al. } \\
\quad 2019\end{array}$ \\
\hline & L. gasseri CRL1314 & $\mathrm{H}_{2} \mathrm{O}_{2}$ production & $\begin{array}{l}\text { Ocaña et al. 1999; } \\
\text { De Gregorio et al. } \\
2019\end{array}$ \\
\hline & L. gasseri CRL1320 & $\begin{array}{c}\mathrm{H}_{2} \mathrm{O}_{2} \text { and lactic acid production, high hydrophobicity, pathogens } \\
\text { inhibition, biofilm formation }\end{array}$ & $\begin{array}{c}\text { Ocaña et al. } \\
\text { 1999; } \\
\text { Leccese Terraf et } \\
\text { al. 2012; } \\
\text { De Gregorio et al. } \\
\quad 2019\end{array}$ \\
\hline & L. gasseri CRL1322 & $\mathrm{H}_{2} \mathrm{O}_{2}$ production & $\begin{array}{l}\text { Ocaña et al. 1999; } \\
\text { De Gregorio et al. } \\
\quad 2019\end{array}$ \\
\hline & L. gasseri CRL1509 & $\begin{array}{l}\mathrm{H}_{2} \mathrm{O}_{2} \text { and lactic acid production, high hydrophobicity, } \\
\text { selfaggregation, pathogens inhibition, colonization of BALB/c } \\
\text { mice vaginal tract, adhesion to fibrinogen and mucin }\end{array}$ & $\begin{array}{c}\text { Ocaña et al. } \\
\text { 1999; } \\
\text { Juárez Tomas et } \\
\text { al. 2011; } \\
\text { De Gregorio et al. } \\
2019\end{array}$ \\
\hline & L. jensenii CRL1313 & $\mathrm{H}_{2} \mathrm{O}_{2}$ production, high hydrophobicity & $\begin{array}{l}\text { Ocaña et al. 1999; } \\
\text { De Gregorio et al. } \\
2019\end{array}$ \\
\hline & L. jensenii CRL1317 & High hydrophobicity & Ocaña et al. 1999 \\
\hline & L. jensenii CRL1333 & $\mathrm{H}_{2} \mathrm{O}_{2}$ production, high hydrophobicity & $\begin{array}{l}\text { Ocaña et al. 1999; } \\
\text { De Gregorio et al. } \\
2019\end{array}$ \\
\hline & L. jensenii CRL1349 & $\mathrm{H}_{2} \mathrm{O}_{2}$ production & $\begin{array}{l}\text { Ocaña et al. 1999; } \\
\text { De Gregorio et al. } \\
2019\end{array}$ \\
\hline & $\begin{array}{c}\text { L. } \\
\text { johnsonii CRL1292 }\end{array}$ & $\mathrm{H}_{2} \mathrm{O}_{2}$ production & $\begin{array}{l}\text { Ocaña et al. 1999; } \\
\text { De Gregorio et al. } \\
2019 \\
\end{array}$ \\
\hline & $\begin{array}{l}\text { L. } \\
\text { salivarius CRL1296 }\end{array}$ & $\mathrm{H}_{2} \mathrm{O}_{2}$ production & $\begin{array}{l}\text { Ocaña et al. 1999; } \\
\text { De Gregorio et al. } \\
\quad 2019\end{array}$ \\
\hline & $\begin{array}{l}\text { L. } \\
\text { salivarius CRL1328 }\end{array}$ & bacteriocin production & $\begin{array}{l}\text { Ocaña et al. 1999; } \\
\text { Vera Pingitore et } \\
\quad \text { al. } 2009 \\
\end{array}$ \\
\hline $\begin{array}{l}\text { Facultative } \\
\text { heterofermentative }\end{array}$ & $\begin{array}{c}L . \\
\text { paracasei CRL1512 }\end{array}$ & $\mathrm{H}_{2} \mathrm{O}_{2}$ production & $\begin{array}{l}\text { Ocaña et al. 1999; } \\
\text { De Gregorio et al. } \\
2019\end{array}$ \\
\hline & $\begin{array}{c}\text { L. } \\
\text { rhamnosus CRL1332 }\end{array}$ & $\begin{array}{l}\mathrm{H}_{2} \mathrm{O}_{2} \text { production, high hydrophobicity, biofilm formation, high } \\
\text { resistance to lyophilization, pathogens inhibition, colonization of } \\
\text { BALB/c mice vaginal tract, adhesion to fibrinogen and mucin }\end{array}$ & $\begin{array}{l}\text { Ocaña et al. } \\
\text { 1999; } \\
\text { Juárez Tomas et } \\
\text { al. 2005, 2011; } \\
\text { Leccese Terraf et } \\
\text { al. 2012; } \\
\text { De Gregorio et al. } \\
2019\end{array}$ \\
\hline
\end{tabular}




\begin{tabular}{|c|c|c|c|}
\hline & $\begin{array}{l}\text { L. } \\
\text { rhamnosus CRL1511 }\end{array}$ & $\begin{array}{c}\mathrm{H}_{2} \mathrm{O}_{2} \text { production, high hydrophobicity, biofilm formation, } \\
\text { adhesion to fibrinogen and mucin }\end{array}$ & $\begin{array}{c}\text { Ocaña et al. 1999; } \\
\text { Leccese Terraf et } \\
\text { al. 2012; } \\
\text { De Gregorio et al } \\
2019\end{array}$ \\
\hline \multirow[t]{4}{*}{$\begin{array}{l}\text { Obligate } \\
\text { heterofermentative }\end{array}$} & $\begin{array}{c}L . \\
\text { fermentum CRL1287 }\end{array}$ & $\mathrm{H}_{2} \mathrm{O}_{2}$ production, high hydrophobicity & $\begin{array}{l}\text { Ocaña et al. 1999; } \\
\text { De Gregorio et al. } \\
2019\end{array}$ \\
\hline & L. reuteri CRL 1324 & $\begin{array}{c}\mathrm{H}_{2} \mathrm{O}_{2} \text { and lactic acid production, high hydrophobicity, biofilm } \\
\text { formation, pathogens inhibition, colonization of BALB/c vaginal } \\
\text { tract mice, adhesion to fibrinogen and mucin }\end{array}$ & $\begin{array}{c}\text { Ocaña et al. } \\
\text { 1999; } \\
\text { Leccese Terraf et } \\
\text { al. 2012, 2016; } \\
\text { De Gregorio et al. } \\
\text { 2015, } 2019\end{array}$ \\
\hline & L. reuteri CRL1327 & $\mathrm{H}_{2} \mathrm{O}_{2}$ production, selfaggregation, biofilm formation & $\begin{array}{c}\text { Ocaña et al. } \\
\text { 1999; } \\
\text { Leccese Terraf et } \\
\text { al. 2012; } \\
\text { De Gregorio et al. } \\
2019 \\
\end{array}$ \\
\hline & L. mucosae CRL1508 & $\mathrm{H}_{2} \mathrm{O}_{2}$ production, high hydrophobicity & $\begin{array}{l}\text { Ocaña et al. 1999; } \\
\text { De Gregorio et al. } \\
2019\end{array}$ \\
\hline
\end{tabular}

Table 2. Phytocompounds (pure and combined extracts) assayed in this work 


\begin{tabular}{|c|c|c|c|c|c|}
\hline $\mathrm{N}^{\circ}$ & $\begin{array}{l}\text { Scientific } \\
\text { name }\end{array}$ & Vulgar name & Abbreviation & Extracts & $\begin{array}{l}\text { Ingredients into the } \\
\text { mixture }\end{array}$ \\
\hline 1 & Aesculus & AESCULUS & Aes* & $\bar{C}$ & $\begin{array}{l}\text { Castaño de India. Bolsa de } \\
\text { pastor. Hamamelis. } \\
\text { Manzanilla. Calendula }\end{array}$ \\
\hline 2 & Bacharis & BACHARIS & Bac* & $\bar{C}$ & $\begin{array}{l}\text { Bacharis. Poleo. } \\
\text { Manzanilla. Cola de } \\
\text { Caballo. Menta }\end{array}$ \\
\hline 3 & Betula & BETULA & Bet* & $\mathrm{C}$ & $\begin{array}{l}\text { Diente de leon. Palo azul. } \\
\text { Peperina menta. Cola de } \\
\text { caballo }\end{array}$ \\
\hline 4 & Carica papaya & CARICA & Car & $\mathrm{P}$ & \\
\hline 5 & $\begin{array}{c}\text { Hydrocotile } \\
\text { asiática }\end{array}$ & CENTELLA & Cen & $\mathrm{P}$ & \\
\hline 6 & Chelidonium & CHELIDONIUM & Che* & $\bar{C}$ & $\begin{array}{l}\text { Celidonia. Diente de leon. } \\
\text { Boldo. Romero }\end{array}$ \\
\hline 7 & Equisetum & EQUISETUM & Equ* & $\mathrm{C}$ & $\begin{array}{l}\text { Palo pichi. Palo azul.Yerba } \\
\text { meona }\end{array}$ \\
\hline 8 & $\begin{array}{c}\text { Dryopteris filix } \\
\text { mas }\end{array}$ & FILIX MAS & Fil* & $\mathrm{C}$ & $\begin{array}{l}\text { Cuassia. Cola de caballo. } \\
\text { Paico. Ruda }\end{array}$ \\
\hline 9 & Hamamelis & HAMAMELIS & Ham* & $\bar{C}$ & $\begin{array}{l}\text { Hamamelis. Calendula. } \\
\text { Manzanilla }\end{array}$ \\
\hline 10 & Lippia & LIPPIA & Lip* & $\bar{C}$ & $\begin{array}{l}\text { Poleo. Ruda. Palo azul. } \\
\text { Yerba de pollo. Chañar }\end{array}$ \\
\hline 11 & Matricaria & MATRICARIA & Mat* & $\mathrm{C}$ & $\begin{array}{l}\text { Manzanilla. Llanten. } \\
\text { Marcela. Burro. Tomillo }\end{array}$ \\
\hline 12 & $\begin{array}{c}\text { Perilla } \\
\text { frutescens }\end{array}$ & PERILLA & Per & $\mathrm{P}$ & \\
\hline 13 & $\begin{array}{c}\text { Plantago } \\
\text { lanceolata }\end{array}$ & PLANTAGO & Pla & $\bar{P}$ & \\
\hline 14 & Uva ursi & UVA URSI & Uva* & $\mathrm{C}$ & $\begin{array}{l}\text { Uva Ursi. Cola de } \\
\text { caballo.Hamamelis }\end{array}$ \\
\hline 15 & Zarzaparrilla & ZARZAPARRILLA & Zar* & $\mathrm{C}$ & $\begin{array}{l}\text { Ortiga. Palo Azul. Cola de } \\
\text { caballo }\end{array}$ \\
\hline 16 & $\begin{array}{l}\text { Caléndula } \\
\text { officinalis }\end{array}$ & CALENDULA & $\mathrm{Cal}$ & $\bar{P}$ & \\
\hline 17 & $\begin{array}{c}\text { Aesculus } \\
\text { hippocastanum }\end{array}$ & $\begin{array}{l}\text { CASTANA DE } \\
\text { INDIA }\end{array}$ & Cas & $\mathrm{P}$ & \\
\hline 18 & $\begin{array}{l}\text { Equisetum } \\
\text { arvence }\end{array}$ & $\begin{array}{l}\text { COLA DE } \\
\text { CABALLO }\end{array}$ & Cdc & $\bar{P}$ & \\
\hline 19 & $\begin{array}{l}\text { Echinacea } \\
\text { purpúrea }\end{array}$ & ECHINACEA & Ech & $\mathrm{P}$ & \\
\hline 20 & $\begin{array}{l}\text { Matricaria } \\
\text { recutita }\end{array}$ & MANZANILLA & Man & $\mathrm{P}$ & \\
\hline 21 & Urtica dioica & ORTIGA & Ort & $\mathrm{P}$ & \\
\hline 22 & $\begin{array}{l}\text { Cyclolepis } \\
\text { genistoides }\end{array}$ & PALO AZUL & $\mathrm{Paz}$ & $\mathrm{P}$ & \\
\hline 23 & $\begin{array}{l}\text { Amaranthus } \\
\text { muricatus }\end{array}$ & YERBA MEONA & Yme & $\mathrm{P}$ & \\
\hline 24 & $\begin{array}{c}\text { Acrtostaphylos } \\
\text { uva-ursi }\end{array}$ & UVA URSI & Uva & $\bar{P}$ & \\
\hline 25 & Smilax aspera & ZARZAPARRILLA & Zar & $\mathrm{P}$ & \\
\hline
\end{tabular}


Reference: The * means different phytocompounds extracting into the same solution- "P": Pure extracts (one natural compounds); "C": Combined extracts (mixture of different phytocompounds, which are detailing in the last column)

Table 3. Effects and characteristics of the Liquid Phytocompounds used in this work 


\begin{tabular}{|c|c|c|c|c|c|}
\hline $\begin{array}{c}\text { SCIENTIFIC } \\
\text { NAME }\end{array}$ & $\begin{array}{l}\text { VULGAR } \\
\text { NAME }\end{array}$ & Abbreviation & APPLICATION & USES & PHARMACOPOEIA \\
\hline $\begin{array}{l}\text { Achyrocline } \\
\text { satureioides }\end{array}$ & Marcela & Mar & $\begin{array}{c}\text { Digestive effect, } \\
\text { antidiabetic, } \\
\text { cholagogic, } \\
\text { antispasmodic, } \\
\text { carminative }\end{array}$ & $\begin{array}{l}\text { oral } \\
\text { way }\end{array}$ & $\begin{array}{c}\text { Argentine } \\
\text { annexed } 2009\end{array}$ \\
\hline $\begin{array}{c}\text { Acrtostaphylos } \\
\text { uva-ursi }\end{array}$ & Uva ursi & Uva & $\begin{array}{c}\text { Antibacterial, } \\
\text { astringent, anti- } \\
\text { inflammatory } \\
\text { effects in the } \\
\text { genitourinary } \\
\text { tract; bleaching } \\
\text { agent and control } \\
\text { of } \\
\text { hyperpigmentation } \\
\text { disorders of skin. }\end{array}$ & $\begin{array}{l}\text { oral } \\
\text { way/ } \\
\text { topic } \\
\text { use }\end{array}$ & $\begin{array}{c}\text { Argentine/ British } \\
\text { Pharmacopeia }\end{array}$ \\
\hline $\begin{array}{c}\text { Aesculus } \\
\text { hippocastanum }\end{array}$ & $\begin{array}{c}\text { Castaña de } \\
\text { India }\end{array}$ & Cas & $\begin{array}{l}\text { Improvement the } \\
\text { circulation of } \\
\text { venous return and } \\
\text { the capillary } \\
\text { resistance; } \\
\text { decreases edema } \\
\text { resulting from } \\
\text { lymphatic } \\
\text { congestion or } \\
\text { inflammation. }\end{array}$ & $\begin{array}{l}\text { topic } \\
\text { use }\end{array}$ & $\begin{array}{l}\text { Argentine 8th } \\
\text { edition }\end{array}$ \\
\hline $\begin{array}{c}\text { Aloysia } \\
\text { polystachya }\end{array}$ & Te de burro & Bur & $\begin{array}{c}\text { Digestive and } \\
\text { carminative effect }\end{array}$ & $\begin{array}{l}\text { oral } \\
\text { way }\end{array}$ & $\begin{array}{l}\text { Argentine8th } \\
\text { edition/ } \\
\text { European }\end{array}$ \\
\hline $\begin{array}{c}\text { Alternanthera } \\
\text { pungens }\end{array}$ & $\begin{array}{l}\text { Yerba del } \\
\text { pollo }\end{array}$ & Ypo & Digestive effect & $\begin{array}{l}\text { oral } \\
\text { way }\end{array}$ & $\begin{array}{l}\text { Argentine 6th } \\
\text { edition }\end{array}$ \\
\hline $\begin{array}{l}\text { Amaranthus } \\
\text { muricatus }\end{array}$ & $\begin{array}{l}\text { Yerba } \\
\text { meona }\end{array}$ & Yme & $\begin{array}{c}\text { Diuretic, } \\
\text { antitumor, drastic } \\
\text { purging, warts, } \\
\text { herpes, depurative }\end{array}$ & $\begin{array}{l}\text { oral } \\
\text { way }\end{array}$ & \\
\hline $\begin{array}{c}\text { Atropa } \\
\text { belladonna }\end{array}$ & Belladona & $\mathrm{Bel}$ & $\begin{array}{c}\text { Irritable bowel } \\
\text { syndrome among } \\
\text { others }\end{array}$ & $\begin{array}{l}\text { oral } \\
\text { way }\end{array}$ & $\begin{array}{l}\text { Argentine 8th } \\
\text { edition }\end{array}$ \\
\hline $\begin{array}{c}\text { Bacharis } \\
\text { articulata }\end{array}$ & Bacharis & Bac & Digestive effect & $\begin{array}{l}\text { oral } \\
\text { way }\end{array}$ & $\begin{array}{l}\text { Argentine 6th } \\
\text { edition }\end{array}$ \\
\hline $\begin{array}{l}\text { Caléndula } \\
\text { officinalis }\end{array}$ & Caléndula & $\mathrm{Cal}$ & $\begin{array}{c}\text { Healing and } \\
\text { topical anti- } \\
\text { inflammatory } \\
\text { effect; emulsifier } \\
\text { and astringent } \\
\text { properties; } \\
\text { promote healing of } \\
\text { eczema and other } \\
\text { forms of inflamed } \\
\text { skin (dermatitis); } \\
\text { treatment of } \\
\text { pruritic or }\end{array}$ & $\begin{array}{c}\text { oral } \\
\text { way/ } \\
\text { topic } \\
\text { use }\end{array}$ & $\begin{array}{l}\text { Argentine 8th } \\
\text { edition }\end{array}$ \\
\hline
\end{tabular}




\begin{tabular}{|c|c|c|c|c|c|}
\hline & & & $\begin{array}{l}\text { Inflammatory skin } \\
\text { conditions; } \\
\text { effective for } \\
\text { fungal infections } \\
\text { of the skin and } \\
\text { nails }\end{array}$ & & \\
\hline $\begin{array}{c}\text { Capsella } \\
\text { bursa-pastoris }\end{array}$ & $\begin{array}{c}\text { Bolsa de } \\
\text { pastor }\end{array}$ & $\mathrm{Bdp}$ & healing effect & $\begin{array}{c}\text { topic } \\
\text { use }\end{array}$ & $\begin{array}{l}\text { Argentine/ } \\
\text { Spanish } 4 \text { ta } \\
\text { edition }\end{array}$ \\
\hline Carica papaya & Papaya & Pap & $\begin{array}{c}\text { Digestive effect, } \\
\text { antifebrile, } \\
\text { antihypertensive, } \\
\text { anthelmintic, in } \\
\text { osteoarthritis and } \\
\text { edema. In external } \\
\text { application, } \\
\text { venous ulcers } \\
\text { heal. eczema, } \\
\text { erysipelas, } \\
\text { psoriasis, freckles } \\
\text { and warts } \\
\end{array}$ & $\begin{array}{l}\text { oral } \\
\text { way }\end{array}$ & Mexican \\
\hline $\begin{array}{c}\text { Chelidonium } \\
\text { majus }\end{array}$ & Celidonia & Cel & $\begin{array}{c}\text { Choleretic, } \\
\text { cholagogic, } \\
\text { spasmolytic, mild } \\
\text { laxative; anti- } \\
\text { inflammatory, } \\
\text { antineoplastic, } \\
\text { antiviral and } \\
\text { antifungal } \\
\text { (topical) } \\
\end{array}$ & $\begin{array}{c}\text { oral } \\
\text { way/ } \\
\text { topic } \\
\text { use }\end{array}$ & European \\
\hline $\begin{array}{l}\text { Chenopodium } \\
\text { ambrosioides }\end{array}$ & Paico & Pai & $\begin{array}{l}\text { Eupeptic, diuretic, } \\
\text { emenagogo, } \\
\text { antiparasitic, } \\
\text { febrifuge and } \\
\text { carminative effect; } \\
\text { skin, digestive } \\
\text { cramps, cough and } \\
\text { hemorrhoids } \\
\text { prevent }\end{array}$ & $\begin{array}{l}\text { oral } \\
\text { way }\end{array}$ & $\begin{array}{c}\text { Argentine } \\
\text { annexed } 2009\end{array}$ \\
\hline Cuassia amara & Cuasia & Cua & $\begin{array}{l}\text { Analgesic and } \\
\text { prevents formation } \\
\text { of blood clots }\end{array}$ & $\begin{array}{l}\text { topic } \\
\text { use }\end{array}$ & $\begin{array}{c}\text { Argentine } 4 \text { th } \\
\text { edition }\end{array}$ \\
\hline $\begin{array}{l}\text { Cyclolepis } \\
\text { genistoides }\end{array}$ & Palo azul & Paz & $\begin{array}{l}\text { Antiinflammatory } \\
\text { activity. }\end{array}$ & $\begin{array}{l}\text { oral } \\
\text { way }\end{array}$ & \\
\hline $\begin{array}{c}\text { Dryopteris filix } \\
\text { mas }\end{array}$ & $\begin{array}{c}\text { Helecho } \\
\text { macho }\end{array}$ & Hma & Antiparasitic & $\begin{array}{l}\text { oral } \\
\text { way }\end{array}$ & $\begin{array}{c}\text { Argentine } \\
\text { annexed } 2009\end{array}$ \\
\hline $\begin{array}{l}\text { Echinacea } \\
\text { purpúrea }\end{array}$ & Echinacea & Ech & $\begin{array}{c}\text { Bacterial, viral and } \\
\text { protozoal } \\
\text { infections, } \\
\text { including } \\
\text { infections of the } \\
\text { digestive, } \\
\text { respiratory and }\end{array}$ & $\begin{array}{c}\text { oral } \\
\text { way/ } \\
\text { topic } \\
\text { use }\end{array}$ & European \\
\hline
\end{tabular}




\begin{tabular}{|c|c|c|c|c|c|}
\hline & & & $\begin{array}{c}\text { urinary tracts; } \\
\text { mild septicemia; } \\
\text { states of } \\
\text { weakened, } \\
\text { suppressed or } \\
\text { imbalanced } \\
\text { immunity, } \\
\text { including allergies } \\
\text { and autoimmune } \\
\text { disease; } \\
\text { inflammatory and } \\
\text { purulent } \\
\text { conditions, } \\
\text { including acne, } \\
\text { abscess, furuncles } \\
\text { training; } \\
\text { envenomation. } \\
\text { improve wound } \\
\text { healing, increase } \\
\text { resistance to } \\
\text { infection and to } \\
\text { increase } \\
\text { connective tissue } \\
\text { regeneration, } \\
\text { inflamed skin } \\
\text { conditions and } \\
\text { bacterial } \\
\text { infections }\end{array}$ & & \\
\hline $\begin{array}{l}\text { Equisetum } \\
\text { arvence }\end{array}$ & $\begin{array}{l}\text { Cola de } \\
\text { caballo }\end{array}$ & $\mathrm{Cdc}$ & $\begin{array}{c}\text { Astringent, } \\
\text { antidiarrhoeic, } \\
\text { diuretic, healing } \\
\text { effect, and } \\
\text { emmenagogo } \\
\text { agent }\end{array}$ & $\begin{array}{l}\text { oral } \\
\text { way }\end{array}$ & European \\
\hline $\begin{array}{c}\text { Fabiana } \\
\text { imbricata }\end{array}$ & Palo pichi & Ppi & Diuretic & $\begin{array}{l}\text { oral } \\
\text { way }\end{array}$ & $\begin{array}{c}\text { Argentine 3th } \\
\text { edition }\end{array}$ \\
\hline $\begin{array}{c}\text { Geoffroea } \\
\text { decorticans }\end{array}$ & Chañar & Cha & Hemorrhoids & $\begin{array}{l}\text { oral } \\
\text { way }\end{array}$ & $\begin{array}{l}\text { Martínez G J et } \\
\text { al., } 2005 \text { (16). }\end{array}$ \\
\hline $\begin{array}{c}\text { Hamamelis } \\
\text { virginiana }\end{array}$ & Hamamelis & Ham & $\begin{array}{c}\text { Astringent, } \\
\text { antiinflammatory, } \\
\text { haemostyptic; } \\
\text { haemorrhoids, } \\
\text { varicose veins; } \\
\text { diarrhoea, mucous } \\
\text { colitis; bruises and } \\
\text { localised, inflamed } \\
\text { swellings. }\end{array}$ & $\begin{array}{c}\text { oral } \\
\text { way/ } \\
\text { topic } \\
\text { use }\end{array}$ & $\begin{array}{c}\text { Argentine 8th } \\
\text { edition }\end{array}$ \\
\hline $\begin{array}{c}\text { Hydrocotile } \\
\text { asiática }\end{array}$ & $\begin{array}{l}\text { Centella } \\
\text { Asiática }\end{array}$ & Cen & $\begin{array}{l}\text { Assists cognitive } \\
\text { function; } \\
\text { facilitates venous } \\
\text { irrigation and } \\
\text { microcirculatory } \\
\text { function; }\end{array}$ & $\begin{array}{c}\text { oral } \\
\text { way/ } \\
\text { topic } \\
\text { use }\end{array}$ & $\begin{array}{c}\text { Argentine 8th } \\
\text { edition }\end{array}$ \\
\hline
\end{tabular}




\begin{tabular}{|c|c|c|c|c|c|}
\hline & & & $\begin{array}{l}\text { modulates } \\
\text { inflammation; } \\
\text { moderates stress } \\
\text { responses; calms } \\
\text { the nervous } \\
\text { system; regulates } \\
\text { connective tissue } \\
\text { function and } \\
\text { promotes healing; }\end{array}$ & & \\
\hline $\begin{array}{l}\text { Lippia } \\
\text { turbinata }\end{array}$ & Poleo & Pol & $\begin{array}{c}\text { Digestion, } \\
\text { diuretic, tonic, } \\
\text { emenagogo }\end{array}$ & $\begin{array}{l}\text { oral } \\
\text { way }\end{array}$ & $\begin{array}{c}\text { Argentine } \\
\text { annexed } 2009\end{array}$ \\
\hline $\begin{array}{c}\text { Margyricar-pus } \\
\text { pinnatus }\end{array}$ & $\begin{array}{c}\text { Yerba de la } \\
\text { pediz }\end{array}$ & Ype & $\begin{array}{c}\text { Depurative blood, } \\
\text { diuretic }\end{array}$ & $\begin{array}{l}\text { oral } \\
\text { way }\end{array}$ & \\
\hline $\begin{array}{c}\text { Matricaria } \\
\text { recutita }\end{array}$ & Manzanilla & Man & $\begin{array}{c}\text { Topical } \\
\text { antiinflammatory } \\
\text { effects, demulcent } \\
\text { and astringent } \\
\text { properties; } \\
\text { Venotonic, } \\
\text { antiedematous, } \\
\text { haemorrhoids; } \\
\text { Topically for } \\
\text { haematoma, } \\
\text { contusions, non- } \\
\text { penetrating } \\
\text { wounds and sports } \\
\text { injuries involving } \\
\text { oedema }\end{array}$ & $\begin{array}{l}\text { oral } \\
\text { way/ } \\
\text { topic } \\
\text { use }\end{array}$ & $\begin{array}{c}\text { Argentine 8th } \\
\text { edition }\end{array}$ \\
\hline $\begin{array}{c}\text { Minthosta-chys } \\
\text { mollis }\end{array}$ & Peperina & Pep & $\begin{array}{c}\text { Antibacterial, } \\
\text { antihistaminic, } \\
\text { hemostatic, } \\
\text { antispasmodic and } \\
\text { antidiarrheal }\end{array}$ & $\begin{array}{l}\text { oral } \\
\text { way/ } \\
\text { topic } \\
\text { use }\end{array}$ & $\begin{array}{l}\text { Argentine 4th } \\
\text { edition }\end{array}$ \\
\hline$\overline{P e u m u s ~ b o l d u s}$ & Boldo & Bol & $\begin{array}{c}\text { Soft laxative; } \\
\text { antipyretic } \\
\text { mechanism }\end{array}$ & $\begin{array}{l}\text { oral } \\
\text { way }\end{array}$ & $\begin{array}{c}\text { Argentine 8th } \\
\text { edition }\end{array}$ \\
\hline $\begin{array}{c}\text { Plantago } \\
\text { lanceolata }\end{array}$ & $\begin{array}{l}\text { Plantago- } \\
\text { llanten }\end{array}$ & Pla & $\begin{array}{c}\text { Gastritis, Ulcers, } \\
\text { Diarrhea, Liver } \\
\text { Diseases; Sores, } \\
\text { Pustules (used } \\
\text { locally) }\end{array}$ & $\begin{array}{l}\text { oral } \\
\text { way/ } \\
\text { topic } \\
\text { use }\end{array}$ & Spanish-European \\
\hline $\begin{array}{c}\text { Ruta } \\
\text { graveolens }\end{array}$ & Ruda & Rud. & Anticonceptive & $\begin{array}{l}\text { oral } \\
\text { way }\end{array}$ & $\begin{array}{c}\text { Argentine } \\
\text { annexed } 2009\end{array}$ \\
\hline Smilax aspera & Zarzaparrilla & Zar & $\begin{array}{l}\text { Astringent, } \\
\text { diuretic, } \\
\text { cardiotonic and } \\
\text { antisifilitic; } \\
\text { healing; }\end{array}$ & $\begin{array}{l}\text { oral } \\
\text { way/ } \\
\text { topic } \\
\text { use }\end{array}$ & French- European \\
\hline $\begin{array}{l}\text { Taraxacum } \\
\text { officinale }\end{array}$ & $\begin{array}{l}\text { Diente de } \\
\text { león }\end{array}$ & Ddl & $\begin{array}{l}\text { Digestive and } \\
\text { diuretic effect }\end{array}$ & $\begin{array}{l}\text { oral } \\
\text { way }\end{array}$ & British \\
\hline $\begin{array}{l}\text { Thymus } \\
\text { vulgaris }\end{array}$ & Tomillo & Tom & $\begin{array}{l}\text { Spasmolytic, } \\
\text { antiseptic and }\end{array}$ & $\begin{array}{l}\text { oral } \\
\text { way/ }\end{array}$ & $\begin{array}{l}\text { Argentine 8th } \\
\text { edition }\end{array}$ \\
\hline
\end{tabular}




\begin{tabular}{|c|c|c|c|c|c|}
\hline & & & $\begin{array}{l}\text { expectorant for } \\
\text { respiratory } \\
\text { conditions; } \\
\text { antimicrobial and } \\
\text { antiviral in topical } \\
\text { application for the } \\
\text { skin and mucous } \\
\text { membranes }\end{array}$ & $\begin{array}{l}\text { topic } \\
\text { use }\end{array}$ & \\
\hline Urtica dioica & Ortiga & Ort & $\begin{array}{c}\text { Diarrhoea, } \\
\text { dysentery, internal } \\
\text { bleeding, chronic } \\
\text { diseases of the } \\
\text { colon, chronic skin } \\
\text { eruptions, bladder } \\
\text { irritations; } \\
\text { topically for burns, } \\
\text { wounds, } \\
\text { nosebleeds, } \\
\text { inflammation of } \\
\text { the mouth or } \\
\text { throat, joint pain } \\
\text { (via the stinging of } \\
\text { the skin around } \\
\text { the joint); orally } \\
\text { for skin rashes. }\end{array}$ & $\begin{array}{c}\text { oral } \\
\text { way/ } \\
\text { topic } \\
\text { use }\end{array}$ & European \\
\hline
\end{tabular}

References: Application: different pharmacological effect of the natural compounds (4, 5, 14, 15, 16, 17). Uses: way of administration. Pharmacopoeia: year of publication and annexes in which they were accepted $(15,16,17)$. All the extracts were obtained to FITOT laboratory, Tucuman- Argentina.

\section{Figures}



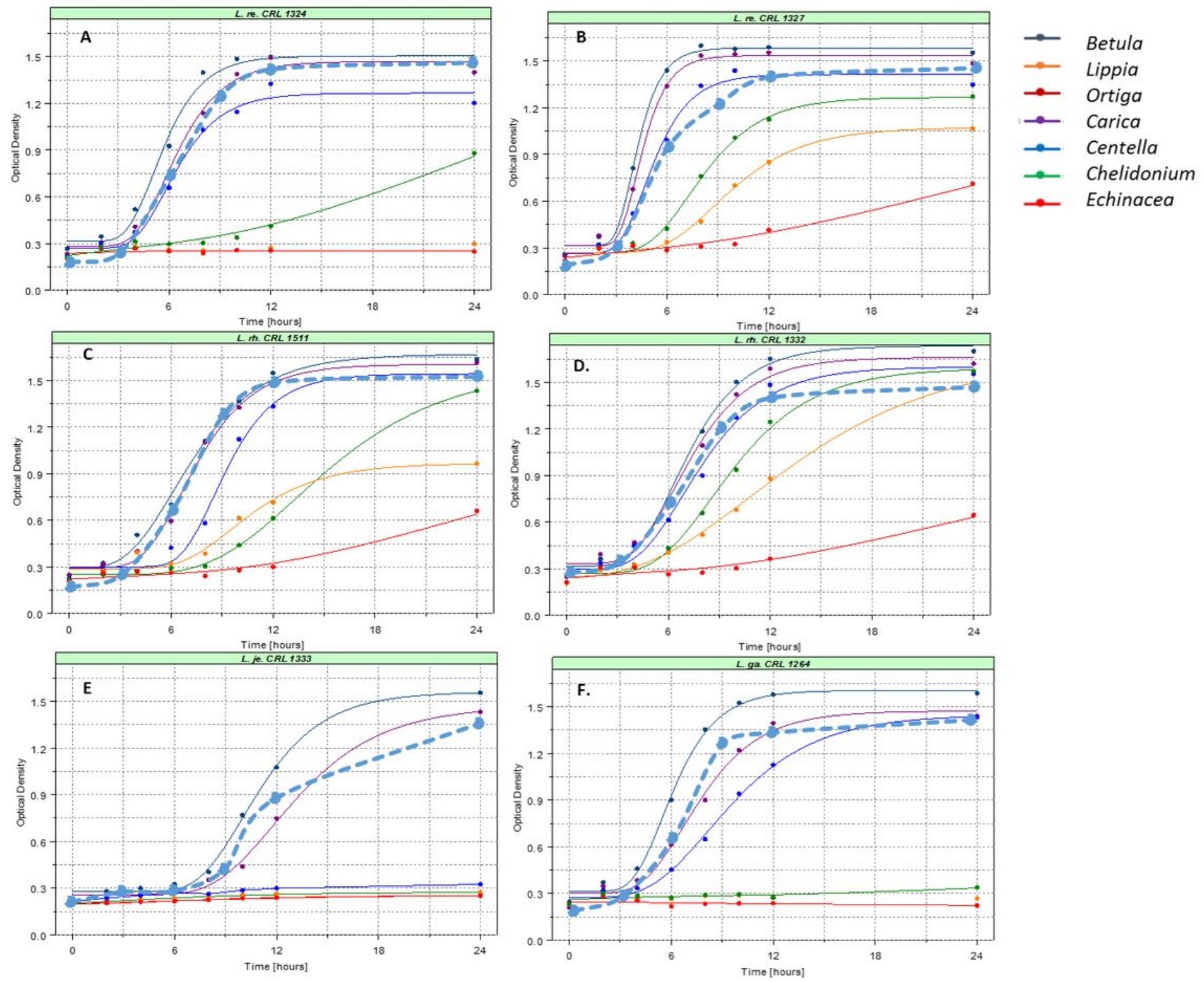

\section{Figure 2}

Kinetics of BVL growth added with different phytocompounds. Fig A-B: obligate homofermentative bacteria ( $\mathrm{OHe}$ ); Fig C- D: facultative heterofermentative (FHe), and Fig E-F: obligate homofermentative lactobacilli (OHo). The growth in standard media (MRS) of each strain of lactobacillus is represented by a dotted line. Different colors represent strains growth with added phytocompounds (Blue: "Betula"; Orange: "Lippia”; Board: “Ortiga”; Violet: “Carica”; Light Blue: “Centella”; Green: “Chelidonium”; Red: “Echinaceae”). 

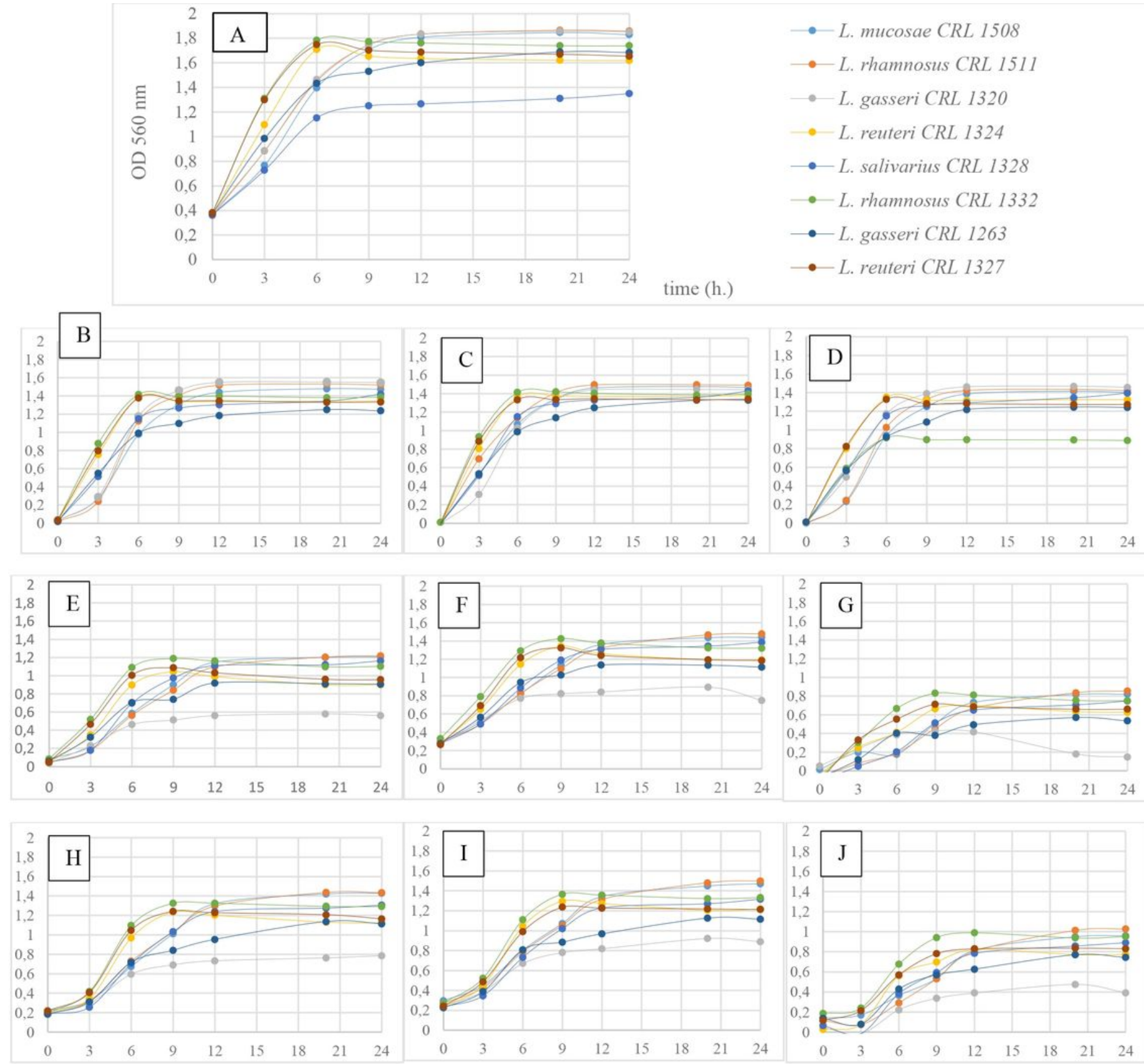

\section{Figure 4}

Kinetic growth of BVL with different solid phytocompounds (solvent: ethanol 40\%). A: control growth of BVL in standard MRS broth B: BVL growth in MRS $+0.75 \mathrm{mg} / \mathrm{ml}$ Allium sativa. C: BVL growth in MRS+ 1.5 $\mathrm{mg} / \mathrm{ml}$ Allium sativa. D: BVL growth in MRS $+3 \mathrm{mg} / \mathrm{ml}$ Allium sativa. E: BVL growth in MRS $+0.75 \mathrm{mg} / \mathrm{ml}$ Hamamelis. F: BVL growth in MRS+ $1.5 \mathrm{mg} / \mathrm{ml}$ Hamamelis. G: BVL growth in MRS+ $3 \mathrm{mg} / \mathrm{ml}$ Hamamelis. $\mathrm{H}$ : BVL growth in MRS+ $0.75 \mathrm{mg} / \mathrm{ml}$ Uva ursi. I: BVL growth in MRS $+1.5 \mathrm{mg} / \mathrm{ml}$ Uva ursi. J: BVL growth in MRS+ $3 \mathrm{mg} / \mathrm{ml}$ Uva ursi 


\section{Node 1}

All selected combinations of strains and phytocompounds

Strains: L.ga. 2263 , L wh. ISOS, Lre.1324, L re.1327, L de.1290, Lde.13/3, Lde. $13 / 4$, L. de. 1349 , Lga 1256, L ga 1264, L/0.1292 Lpa I322, L pa.IS12, L.re.1287, Lith.126I

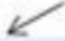

Terminal Node 1 Avg: 0.938, STD: 0.103

N: 128
N: 184
Node 2

Avg: 1.163 , STD: 0.263

N: 56

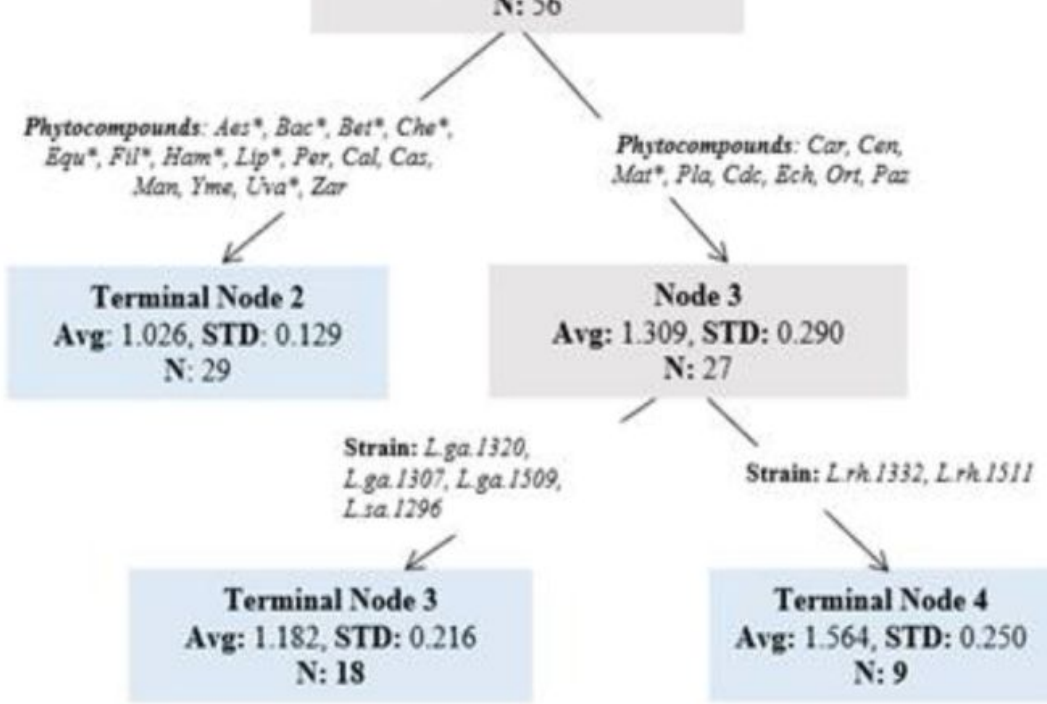

Figure 5

Cart tree of BVL and liquid phytocompounds obtained from the Statistical analysis carried out by SSPP, as indicated in materials and methods section. *represents the extracts assayed as mixture. 


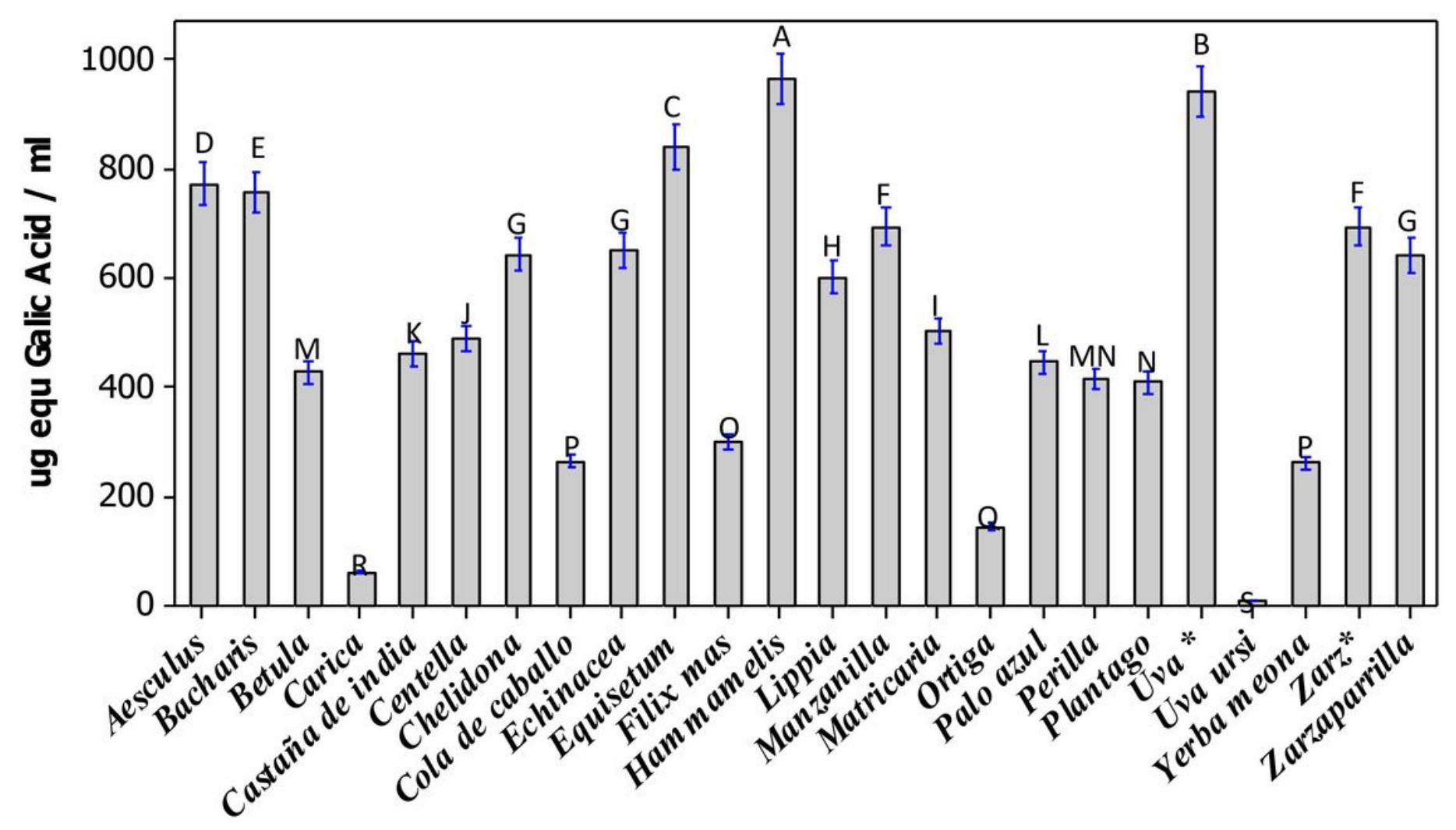

Phytocomopounds

Figure 8

Quantification of phenolic compounds of phytoderivatives. Different letters represent significant differences $(p<0.005)$. 